\title{
Application of Cobit Freamwork 4.1 Method in Information Technology Audit
}

\author{
Alya Rizki \\ Universitas Putra Indonesia "YPTK" Padang, Indonesia \\ Alyaarizkki01@gmail.com
}

\begin{abstract}
To Fine the performance of information technology that can easily make decisions, so that the performance of the technology used is more effective and efficient, it is necessary to carry out an information technology audit at the BPKAD office. In this study, the standard used is COBIT 4.1, Using the calculation of the Maturity Level which represents the level of technology alignment information and objectives of the Agency. The calculation of the Maturity Level value will be carried out in the Acquire and Implement (AI2, AI3, AI4, AI5) and Deliver and Support (DS7, DS10, DS12, DS13) domains. The BPKAD office already uses information technology in every process of its activities. The overall results in the agency reached level 4 (Managed). From the level results obtained, recommendations were made that could be applied by the BPKAD office to reach the desired level, namely level 5 (Optimized) so that it could support the performance of the agency to be even better in terms of information technology.
\end{abstract}

Keywords: Audit, IT , COBIT 4.1, Maturity Level, Acquire and Implement, Deliver and Support.

\section{Introduction}

The development of computer technology and information systems at this time has experienced a very Based on the results of interviews, in the rapid increase, which is in line with the public's need implementation of the use of information technology at for information. Today's society tends to be fast in the Padang City BPKAD, several problems were found, following the flow of technological developments, such as the lack of experts in information technology demanding the availability of fast, precise, and accurate and the non-optimal maintenance of the information information. Every agency, both government and system used, causing the slow handling of system private agencies, definitely needs an information improvements so that it has an impact on employee system that can support its performance to obtain and performance. Then in the use of the application, as well produce information more effectively and as the supporting processes that allow the efficiently[1]. The utilization of information technology implementation of the information technology system, (IT) in the government process can improve efficiency, it is still not effective and efficient because the effectiveness, transparency, and accountability of resources that operate the application are not fully government administration. For the implementation of trained and training in the use of the application is still IT governance to run well, an organization evaluates needed.

the extent to which IT governance is running and can identify improvements that can be made[2]. Regional Asset Financial Management Agency Padang City BPKAD, a Maturity Level analysis is (BPKAD) of the city of Padang is an institution that is carried out. The audit was conducted using the COBIT obliged to assist the Mayor in administering the 4.1 framework and focused on the Acquire and government in the field of financial management and Implement (AI) and Deliver and Support (DS) regional assets of the city of Padang, where all rights domains. COBIT (Control Objectives for Information and obligations of the state can be valued in money, as and Related Technology) is an IT governance well as everything in the form of money or in the form framework to address the gap between technical issues, of money. goods that can be used as state property business risks and control needs. COBIT is a set of related to the implementation of these rights and general guidelines (best practice) for IT management obligations must be managed in an orderly manner and created by the Information Systems Audit and Control obey the laws and regulations. In this regard, BPKAD Association (ISACA) and the IT Governance Institute is obliged to prepare a Revised Strategic Plan based on (ITGI). COBIT integrates good practices in managing the priority scale of development activities that can be information technology and provides a framework for realized by the potential and capabilities of all IT governance that can help understand and manage stakeholders in Padang City. Who in all their work risks and gain benefits related to information technology[3]. 
Based on the description above, to measure the C. Questionnaire Method (Questionnaire) maturity level of Information Technology used to support performance and productivity at BPKAD Padang City, Maturity Level analysis was carried out using the COBIT 4.1 framework, resulting in 2.1 Analysis recommendations to improve IT governance at BPKAD Padang City.

\section{Research Method}

The research framework is a concept or stage that will be carried out in research. The research framework created has the aim of getting results as expected and easy to understand. The steps that will be made in this research are arranged systematically. So it is necessary to develop a research framework. The following will explain the stages of the research contained in Figure.1.

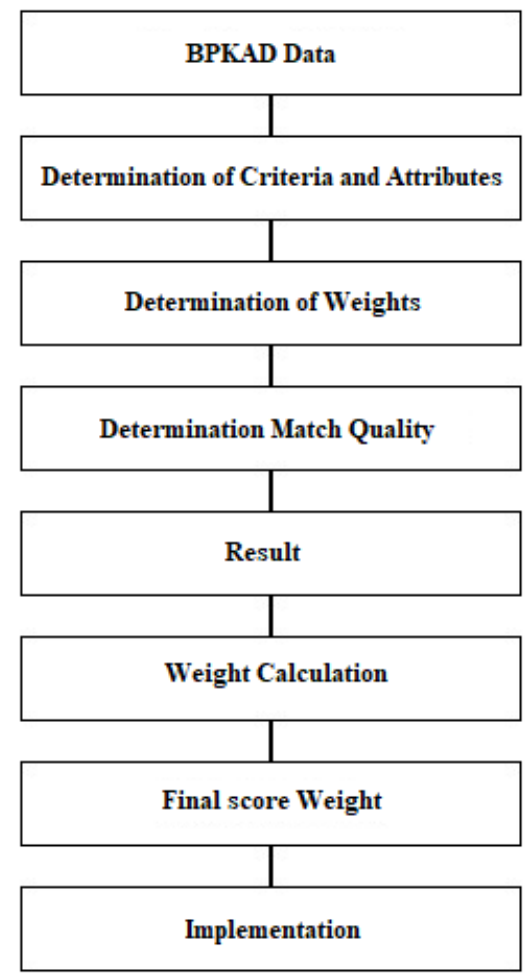

Fig. 1 Stages Of The Research
This method is carried out by distributing questionnaire heets to the parties concerned.

This sub-chapter will be explained analysis which consists of the analysis of the applied system, data analysis, processes, and systems. The explanation of the analysis can be described as follows:

A. Analysis of the applied system

Analysis of the ongoing system to find out and study the problems and weaknesses that exist in the system and determine the needs of system users.

\section{B. Data Analysis}

Analysis of the data obtained directly from the results of interviews and the results of the questionnaires that have been distributed. The data is in the form of an analysis of the use of the system, how the system works, and the information generated by the system.

\section{Process Analysis}

In the analysis process, the method used in this research is the COBIT 4.1 Framework to assist in analyzing the system based on the framework provided by the COBIT 4.1 Framework. Knowledge will be represented by using methods that are useful for finding conclusions about the quality of the system.

\section{System Analysis}

System analysis is the basis for planning and designing the system to be implemented. System analysis is carried out to find out and obtain measurement results from the quality of the system. This system requires some data to then measure the system.

\subsection{System planning}

In the stages of designing this questionnaire calculation system, researchers use the Unified Modeling Language (UML) as tools in explaining the flow of program analysis, where the UML used is:

To get a good system, of course, it cannot be separated from the existing methods or methods when conducting the research process, which includes the preparation of Use case diagram is modeling for the system to be thesis reports and in data collection which consists of made. Use cases are used to find out what functions are three parts, namely:

\section{A. Field Research}

This research was conducted for primary data by visiting companies/agencies to collect data or Class diagram The relationship between classes and a information needed in research, with data collection detailed explanation of each class in the design model techniques:

B. (Observation)

Swallowing data by making direct observations, so as to get clear information about technology, problems Sequence Diagram that depicts the interaction of from using the current system. in the information system and who has the right to use these functions.

\section{B. Class Diagram} of a system, as well as the rules and responsibilities of entities that determine the behavior of the system.

\section{Sequence Diagram}

objects in and around the system. Sequence diagrams

Journal of Computer Science and Information Technology Volume 8 Issue 1 (2021) 12-16 
are used to describe the behavior of a scenario that is After the calculation process is carried out, the results applied to the system to model the implementation of of the calculation of each questionnaire are obtained the programming language.

D. Activity Diagram from the total questions that have been collected by 10 respondents. The following is a method for calculating in determining the index of each domain process that Activity diagrams describe the various streams of has been managed, which can be seen in Table.2. activity in the designed system, where each flow begins, the decisions that may occur, and how they end.

\subsection{Implementation System}

Implementation is a stage that is carried out when the questionnaire calculation application designed is ready to be operated. Implementation aims to confirm the results of the application design, so that users can provide input to application developers.

\section{Result and Discussion}

In measuring the maturity level of the circulation system for borrowing and returning books at the Padang City BPKAD office. A questionnaire is used as a data collection method that will assess the index of each criterion in the measurements made by using the Formula. 1.

$$
\text { Index }=\frac{\epsilon \text { Answer }}{\epsilon \text { Question }}
$$

The index creation scale has a mapping of maturity levels as follows:

1. $0.00-0.49$ is at level 0 (Non-Existent)

2. $0.50-1.49$ is at level 1 (Initial/Ad Hoc)

3. $1.50-2.49$ is at level 2 (Repeatable but Intuitive)

4. $2.50-3.49$ is at level 3 (Defined Process)

5. $3.50-4.49$ is at level 4 (Managed and Measurable)

6. $4.50-5.00$ is at level 5 (Optimised)

The data presented by researchers for respondents in the form of a questionnaire at the BPKAD office in the city of Padang can be seen in Table. 1 .

Table. 1. Data Questionnaire

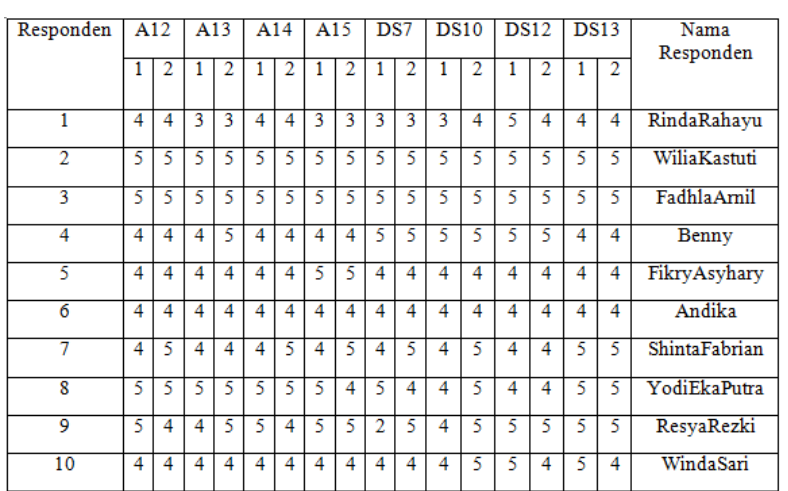

Table. 2 Maturity Level

\begin{tabular}{|c|l|r|r|r|}
\hline No & Domain & Total Pertanyaan & Jumlah Skor Domain & Index \\
\hline 1 & AI2 & 20 & 88 & 4.40 \\
\hline 2 & AI3 & 20 & 87 & 4.35 \\
\hline 3 & AI4 & 20 & 88 & 4.40 \\
\hline 4 & AI5 & 20 & 88 & 4.40 \\
\hline 5 & DS7 & 20 & 89 & 4.45 \\
\hline 6 & DS10 & 20 & 87 & 4.35 \\
\hline 7 & DS12 & 20 & 90 & 4.50 \\
\hline 8 & DS13 & 20 & 91 & 4.55 \\
\hline & & TOTAL & & $\mathbf{3 5 . 4 0}$ \\
\hline & & RATA - RATA & $\mathbf{4 . 4 3}$ \\
\hline
\end{tabular}

The following is a comparative analysis of the maturity level of 15 respondents with the target set, which can be seen in Table. 3 .

Table. 3 GAP comparison

\begin{tabular}{|c|l|r|r|r|}
\hline No & Domain & Index Sekarang & Diharapkan & GAP \\
\hline 1 & AI2 & 4.40 & 5 & 0.60 \\
\hline 2 & AI3 & 4.35 & 5 & 0.65 \\
\hline 3 & AI4 & 4,40 & 5 & 0.60 \\
\hline 4 & AI5 & 4.40 & 5 & 0.60 \\
\hline 5 & DS7 & 4.45 & 5 & 0.55 \\
\hline 6 & DS10 & 4.35 & 5 & 0.65 \\
\hline 7 & DS12 & 4.50 & 5 & 0.50 \\
\hline 8 & DS13 & 4.55 & 5 & 0.45 \\
\hline & & TOTAL & & $\mathbf{4 . 6 0}$ \\
\hline & & RATA - RATA & & $\mathbf{0 . 5 8}$ \\
\hline
\end{tabular}

From the table above, the key is that the maturity of the Acquire and Apply (AI2, AI3, AI4, AI5) and Provide and Support (DS7, DS10, DS12, DS13) sub-domains is $4.35-4.55$ which is at level 4 . The maturity level of the information technology audit at the Padang city BPKAD office using the COBIT 4.1 framework has an average of 4.43 at level 4 (Managed and Measurable), while the maturity level target achieved by the Padang city BPKAD office is level 5 (Optimized). From this comparison, it can be obtained GAP with an average of 0.58 This indicates that the target maturity level has not been achieved as expected by the Padang City BPKAD office. The results of the recommendations obtained can be seen in the Table. 4.

Table. 4 Recommended Results

\begin{tabular}{lllll}
\hline No & Domain & Index & Recommendation \\
\hline 1 & AI2 & (Acquire & 4.40 & From the results obtained with the expected level of comparison, the GAP results are \\
& and & Maintain & & 0.60. So the recommendation given is that the Padang city BPKAD office has obtained \\
\hline
\end{tabular}

Journal of Computer Science and Information Technology Volume 8 Issue 1 (2021) 12-16 
Application

Software)

2 AI3 (Acquire and Maintain Technology Infrastructure)

$3 \quad$ AI4 (Enable Operation and Usage)

\section{$4 \quad$ AI5}

Resource

(IT 4.40

Procurement)

5

$\begin{array}{lr}\text { DS7 } & \text { (Educate } \\ \text { and } & \text { Train } \\ \text { Users) } & \end{array}$

Users)

DS10 (Manage Problems)

\section{DS12}

(Managing

Physical

Environment)

\section{DS13}

(Managing

Operations) and maintained application software properly, so it is necessary to continue to develop steps in software maintenance to make it even better.

4.35 From the results obtained with the expected comparison, the GAP result is 0.65 . So the recommendation given is that the BPKAD in the field of state-owned goods has developed and maintains the technological infrastructure well, but the need for infrastructure maintenance by related parties and carried out periodically for continuous better development.

4,40 From the results obtained with the expected comparison, a GAP of 0.60 is obtained. So the recommendation given is that the Padang City BPKAD office has carried out operations and uses it well. It is necessary to conduct socialization related to the steps for operating and using technology to related parties. Socialization is carried out in the form of training and knowledge transfer to system users.

From the results obtained with the expected comparison, a GAP of 0.60 is obtained. So the recommendation given is that the Padang city BPKAD office on the procurement of IT resources must be aligned with the plans and resource needs of the BPKAD office in the field of state property.

From the results obtained with the expected comparison, the GAP result is 0.55 . So the recommendation given is that the Padang City BPKAD needs program training and user education so that the application can be utilized optimally to provide benefits for the Padang City BPKAD.

4.35 From the results obtained with the expected comparison, the GAP result is 0.65 . So the recommendation given is the BPKAD office in the field of state property which needs to be understood about the benefits of problem management, any possible problems that have occurred, and documenting any problems that have been resolved with the aim of increasing employee productivity in order to move towards a better direction.

4.50 From the results obtained with the expected comparison, a GAP of 0.50 is obtained. So the recommendation given is the Padang city BPKAD office the need for environmental control carried out by the operational section. In carrying out control and supervision, it is necessary to allocate funds with the aim of assisting the maintenance and protection of important assets. The need to protect and maintain the physical environment with security procedures both in terms of hardware and personnel.

4.55 From the results obtained with the expected comparison, the GAP is 0.45. So the recommendation given is that the Padang city BPKAD office needs to increase understanding of the importance of operational roles supported by more active management and implementation of procedures to protect sensitive outputs, as well as the need for instructions on what to do and when to do it. Management can be done by carrying out routine, scheduled management, and clear assignment placements.

\section{Conclusion}

After researching the application of the COBIT 4.1 method in an information technology audit at the Padang City BPKAD office, based on the data obtained and analyzed that has been done, the authors can conclude, including: It can be seen that the maturity level of the subdomains AI2, AI3, AI4, AI5, DS7, DS10, DS12, DS13 is in the range of $4.35-4.55$ which is at level 4 (Managed and Measurable). And the GAP value of subdomain AI2, AI3, AI4, AI5, DS7, DS10, $\mathrm{DS} 12$, DS13 is in the range of 0.58 with the target maturity level to be achieved by the Padang City BPKAD office is level 5 (Optimised). This shows that the performance of technology governance at the Padang City BPKAD office needs to be further improved so that information technology governance at the Padang City BPKAD office becomes more optimal.
It can be seen that the maturity level of the information technology audit at the Padang City BPKAD office using the COBIT 4.1 framework is 4.43 at level 4 (Managed and Measurable). Meanwhile, the target maturity level that the BPKAD office wants to achieve in the city of Padang is level 5 (Optimised). From this comparison, a GAP of 0.58 can be obtained, this indicates that the maturity level target has not been achieved as expected by the Padang city BPKAD office.

\section{References}

1] Elfiondri, Zaitul, \& Rina, N. (2021). Tradition, cultural contact Majid, S. (2019). Audit Tata Kelola Teknologi Informasi pada Dinas Komunikasi dan Informatika (DISKOMINFO) Kota Bandar Lampung Menggunakan Kerangka Kerja COBIT 4.1 Domain Plan and Organise dan Acquire and Implement. doi:10.31219/osf.io/yuehf

[2] Fajriani, F., Jatmika, A. H., \& Ulum, L. M. (2020). Sistem Informasi Pengelolaan Arsip Surat Di Kantor BPKAD Provinsi 
Nusa Tenggara Barat Berbasis WEB Dengan PHP MySQL. Jurnal Begawe Teknologi Informasi (JBegaTI), 1(1). doi:10.29303/jbegati.v1i1.158

[3] Farell, G., Saputra, H. K., \& Novid, I.(2018). Rancang Bangun Sistem Informasi Pengarsipan Surat Menyurat (Studi Kasus Fakultas Teknik UNP). JTIP: Jurnal Teknologi Informasi dan Pendidikan, 11(2), 55-62. http://tip.ppj.unp.ac.id/index.php/tip/article/view/142

[4] Andry, J., \&Christianto, K. (2018). "Audit Menggunakan COBIT 4.1 dan COBIT 5 dengan Case Study".Yogyakarta :Teknosain.

[5] Pawan, E., Utami, E., \& Nasiri, A. (2019). Mengukur Tingkat Kematangan Tata Kelola Sistem Informasi Akademik Menggunakan COBIT 4.1 dan Balanced Scorecard. Creative $\begin{array}{llll}\text { Information Technology Journal, 5(2), } 127 . & \end{array}$ https://doi.org/10.24076/citec.2018v5i2.180

[6] Oktaviani Sirait, L., \& Tristiyanto, T. (2017). AUDIT TEKNOLOGI INFORMASI PADA DEALER MOBIL XYZ DI BANDAR LAMPUNG DENGAN MENGGUNAKAN PENDEKATAN COBIT 4.1. Jurnal Komputasi, 5(1), 42-49. doi:10.23960/komputasi.v5i1.1462

[7] Prasetyo, A., \& Mariana, N. (2011). Analisis Tata Kelola Teknologi Informasi ( It Governance ) pada Bidang Akademik dengan Cobit Frame Work Studi Kasus pada Universitas Stikubank Semarang. Jurnal Teknologi Informasi DINAMIK, 16(2), 139-149.

[8] Hanief, S. (2015). Audit Ti Untuk Menemukan Pola Best Practice Pengelolaan Ti Pada Perbankan (Studi Kasus Pt. Bank Syariah Mandiri Cabang Denpasar). Lontar Komputer, 4(3), 324-335. https://doi.org/10.24843/LKJITI

[9] Majid, S. (2019). Audit Tata Kelola Teknologi Informasi pada Dinas Komunikasi dan Informatika (DISKOMINFO) Kota Bandar Lampung Menggunakan Kerangka Kerja COBIT 4.1 Domain Plan and Organise dan Acquire and Implement. doi:10.31219/osf.io/yuehf

[10] Fajriani, F., Jatmika, A. H., \& Ulum, L. M. (2020). Sistem Informasi Pengelolaan Arsip Surat Di Kantor BPKAD Provinsi Nusa Tenggara Barat Berbasis WEB Dengan PHP MySQL. Jurnal Begawe Teknologi Informasi (JBegaTI), 1(1). doi:10.29303/jbegati.vli1.158

[11] Farell, G., Saputra, H. K., \& Novid, I.(2018). Rancang Bangun Sistem Informasi Pengarsipan Surat Menyurat (Studi Kasus Fakultas Teknik UNP). JTIP: Jurnal Teknologi Informasi dan Pendidikan, 11(2), 55-62. http://tip.ppj.unp.ac.id/index.php/tip/article/view/142

[12] Andry, J., \&Christianto, K. (2018). "Audit Menggunakan COBIT 4.1 dan COBIT 5 dengan Case Study".Yogyakarta :Teknosain.

[13] Pawan, E., Utami, E., \& Nasiri, A. (2019). Mengukur Tingkat Kematangan Tata Kelola Sistem Informasi Akademik Menggunakan COBIT 4.1 dan Balanced Scorecard. Creative Information Technology Journal, 5(2), 127. https://doi.org/10.24076/citec.2018v5i2.180

[14] Oktaviani Sirait, L., \& Tristiyanto, T. (2017). AUDIT TEKNOLOGI INFORMASI PADA DEALER MOBIL XYZ DI BANDAR LAMPUNG DENGAN MENGGUNAKAN PENDEKATAN COBIT 4.1. Jurnal Komputasi, 5(1), 42-49. doi:10.23960/komputasi.v5i1.1462

[15] Prasetyo, A., \& Mariana, N. (2011). Analisis Tata Kelola Teknologi Informasi ( It Governance ) pada Bidang Akademik dengan Cobit Frame Work Studi Kasus pada Universitas Stikubank Semarang. Jurnal Teknologi Informasi DINAMIK, 16(2), 139-149.

[16] Hanief, S. (2015). Audit Ti Untuk Menemukan Pola Best Practice Pengelolaan Ti Pada Perbankan (Studi Kasus Pt. Bank Syariah Mandiri Cabang Denpasar). Lontar Komputer, 4(3), 324-335. https://doi.org/10.24843/LKJITI

[17] Rachmatsyah, A. D. (2018). Pengembangan Aplikasi Aok-Jek Menggunakan Kerangka Kerja COBIT 4.1 Untuk Meningkatkan Pelayanan Terhadap Pelanggan. JATISI (Jurnal Teknik Informatika Dan Sistem Informasi), 5(1), 24-35. doi:10.35957/jatisi.v5i1.111

[18] Dennis E. (2014). "Audit Sistem Informasi System Application And Product In Data Processing (SAP) Pengadaan Material Dengan Menggunakan Kerangka Kerja Cobit 4.1 Pada Kantor Pusat Di Pt. Pindad (Persero)". Skripsi.Bandung: Universitas Komputer Indonesia.

[19] Rahmawati, S., Andini, S., \& Zefriyenni, Z.(2018). Perancangan Program Permainan Untuk Menunjang Minat Belajar Anak Usia Dini Menggunakan ADOBE FLASH CS3. TEKNOLOGI,

$6(2)$. http://lppm.upiyptk.ac.id/TEKNOLOGI/index.php/TEKNOLO GI/article/view/114/128

[20] Manalu, M. R.(2015). Implementasi Sistem informasi penyewaan mobil pada cv. btn padang bulan dengan metode waterfall. Jurnal Mantik Penusa, 18(2). http://ejurnal.pelitanusantara.ac.id/index.php/mantik/article/view/77

[21] Torre, D., Labiche, Y., Genero, M., Baldassarre, M. T., \& Elaasar, M.(2018). UML diagram synthesis techniques: a systematic mapping study. In Proceedings of the 10th International Workshop on Modelling in Software Engineering (pp. 33-40). https://doi.org/10.1145/3193954.3193957

[22] Hasan, H., \& Patrie, H.(2019). Implementasi Analisa Dan Perancangan Sistem Dengan Konsep Electronic Customer Relationship Management (E-CRM) SMPN 245 Jakarta Selatan. Idealis: InDonEsiA journaL Information System, 2(3), $157-165$.

http://jom.fti.budiluhur.ac.id/index.php/IDEALIS/article/view/ $887 / 551$

[23] Pratama, I. P. A. E., \& Agus, I. P. (2014). Sistem Informasi dan Implementasinya. bandung: Informatika Bandung.

24] Kristanto, A.(2018). "Perancangan Sistem Informasi dan Aplikasinya (Edisi Revisi)". Yogyakarta. GAVA MEDIA.

[25] Susandi, B. A. (2014). Audit Tata Kelola Teknologi Informasi Menggunakan COBIT 4.1 Pada PTPN VII Unit Usaha Betung. Jurnal Mahasiswa Teknik Informatika, 12.

[26] AS, R., \& Shalahuddin, M. (2019). Rekayasa Perangkat Lunak Terstruktur \& Berorientasi Objek. Informatika Bandung, Bandung.

[27] Istiana, Y. \&. (2007).Teknologi Informasi \& Komunikasi. Bogor: Yudhistira.

[28] Hutahaean, J. (2014).Konsep Sistem Informasi. Yogyakarta: Deepublish.

[29] Irwansyah, E. (2014).Pengantar Teknologi Informasi. Yogyakarta: Deepublish.

[30] Gantz, S. D. (2014).Metode Audit Teknologi Informasi. 1-4.

[31] Fatyansyah. (2015). "Basis Data". Bandung. Informatika Bandung.

[32] Mandala, E. P. W. (2015). Web Programing, Project 1 epwm forum. Yogyakarta: Andi 